\title{
珠三角村镇建成区的空间型态： 特征、类型和产业影响因素
}

\author{
李极恒 ${ }^{1,2}$, 龚 岳 ${ }^{1,2^{*}}$, 李贵才 1,2 \\ (1. 北京大学深圳研究生院城市规划与设计学院, 广东 深圳 518055 ; \\ 2. 北京大学(深圳)未来城市实验室, 广东 深圳 518055)
}

\begin{abstract}
摘 要: 改革开放以来,珠三角地区的工业迅速发展, 村镇土地利用快速非农化, 其中以东莞、中山、佛山 3 市最为典 型。论文以 3 市为案例, 探讨 2010 年来珠三角村镇建成区空间型态。研究数据主要包括广东省 2015 年土地利用 现状数据和 2009-2015 年间 3市的土地利用数据。首先, 通过斑块密度、空间离散度、空间均匀度、平均斑块面积、 分形维数、景观破碎度、缓冲区分析、Moran's $I$ 指数这 8 个指标, 分析建设用地的空间形态特征。其次, 分析工业用 地与非工业建设用地、建设用地与交通道路的空间分布关系, 比较并总结 3 市的村镇建成区空间类型。最后,基于 灰色关联分析法, 探讨影响空间类型的产业发展因素。研究发现, 东莞村镇建设用地呈现高度破碎均匀分布型, 佛 山呈现团状离散型, 中山介于二者之间, 为中度碎化分散型; 3 市的产业发展能较大程度上影响其形成不同的建成 区空间型态。未来,基于产业经济作为村镇建成区空间特征变化的主因,珠三角可以结合粤港澳大湾区规划建设, 通过调整产业结构、布局以及交通和土地利用,优化村镇空间布局。
\end{abstract}

关 键 词: 建成区; 空间类型; 土地利用;产业因素; 珠三角村镇

村镇空间发展是中国城乡发展的重要节点。 在 20 世纪八九十年代,伴随快速工业化和城市化, 东南沿海一带村镇建设快速发展,形成了著名的苏 南、温州和珠三角工业化模式(顾朝林等, 2008), 极 大地促进了中国的工业化和城镇化发展。珠三角 模式以东莞、中山、佛山为典型代表, 形成了 “三来 一补”外向型的东莞模式(薛凤旋等, 1997)、以地方 国营经济为龙头带动乡镇企业和外资共同发展的 中山模式、以镇办集体企业为主的顺德模式, 以及 县-镇-管理区-联户一个体 “五个轮子一起转” 的南 海模式(许学强等, 1995; 李立勋, 1997)。具体而言, 东莞 “三来一补”企业技术门槛低, 在土地和劳动力
低廉的农村“遍地开花”,规模较小。中山以公有企 业为依托兴建产业园, 引进技术发展制造业, 建设 用地由中心城区向外围镇区扩展。佛山兴办乡镇 集体和个体私营企业, 主要为电器机械及器材制造 业,形成一批中大型企业。这些村镇在地理空间上 形成了在产业(工业与农业)、土地(工业与农业用 地)、人口(城市与农村居民)等方面高度混合的 Desakota 模式(Sui et al, 2001; Chen et al, 2017)。“十八 大”以来, 国家尤为重视村镇发展, 新型城镇化战略 凸显镇域空间在中国城市化进程的地位,而 2017 年 提出的乡村振兴战略提升了乡村发展的重要性,村 镇空间发展的节点作用将更加凸显。

收稿日期: 2018-10-04; 修订日期: 2019-01-12。

基金项目: 国家自然科学基金应急管理项目(41641006); 广东省自然科学基金自由探索项目(2017A030313248); 北京大学(深 圳)未来城市实验室铁汉科研开放课题基金。[Foundation: Emergency Management Project of National Natural Science Foundation of China, No. 41641006; Free Exploration Project of Natural Science Foundation of Guangdong Province of China, No. 2017A030313248; Peking University (Shenzhen) Future Urban Laboratory Tie Han Foundation. ]

第一作者简介:李极恒(1993-), 海南琼山人, 硕士生, 主要从事城市与区域规划研究。E-mail: lijiheng@pku.edu.cn

*通信作者简介: 龚岳(1977一), 湖南长沙人, 博士, 助理教授, 博士生导师, 研究方向为大城市周边区与小城镇、城市治理与乡 城移民、住房与社区。E-mail: gongyue@pkusz.edu.cn 
珠三角土地利用快速变化是中国村镇土地非 农化的典型代表, 研究重点为用地分布、扩展特征 及其影响因素和动力机制等方面。其土地利用的 总体空间格局为典型的 “核心-边缘” 结构(王开泳 等, 2008), 表现为在珠江口两岸高密度集聚开发 (Dai et al, 2010), 外围地区以镇级工业区为主体的 “小集聚、大分散”式的分散建设(叶玉瑶等, 2007; 丁俊等,2016)。在具体的分布上具有空间指向性, 如交通水系指向(Fan et al, 2009)、中心地指向(王爱 民等, 2007)、城镇倾向(叶玉瑶等, 2011), 形成交通 导向的松散绵延和组团集聚2种空间形态(李珽等, 2014)。在村镇工业化进程中, 农田急剧流失, 建设 用地无序扩张(van Wee, 2002), 用地相互混杂、空间 不紧凑和景观破碎现象严重, 不利于形成规模生产 和改善人居环境(韩非等, 2011)。近年来, 东莞各镇 的土地利用蔓延、填充式发展, 原本犬牙交错、契形 分布在农用地之间的建设用地连接成片, 更加集中 紧凑(郑艳婷等, 2003; 伍灵晶等, 2017); 中山的建设 用地规模扩大, 形态趋于规则和聚合 (林媚珍等, 2010); 佛山兴建大型集约式工业园区,引导工业用 地从无序分散到适度集聚, 从混合到分区(李珽等, 2014; 梁励韵等, 2014)。

产业发展、人口、政策和区位等是土地利用变 化的主要因素(叶嘉安等, 1999; 间小培等, 2006; 杨 宝龙等, 2009; 叶玉瑶等, 2010; 李珽等, 2014; 丁俊 等, 2016)。具体而言, 产业发展为建设用地扩展提 供了根本动力, 生产组织模式与产业结构决定了用 地特点(叶玉瑶等, 2011)。人口增长为产业发展提 供了劳动力, 同时也引起对土地利用空间需求的增 加。政策因素是产业发展的制度环境, 产业政策、 制度改革和政府规划管控等对产业形成及其用地 布局起到引导作用。区位因素主要表现为土地、交 通成本差异对企业效益的影响, 进而影响土地利用 次序(Chen et al, 2013)。

在珠三角, 产业发展是村镇工业化的重要推力 和土地利用变化的最重要因素(Weng, 2002; 田莉, 2015)。改革开放初期, 珠三角主要依靠土地高投 人、外力驱动实现经济增长, 形成劳动力密集型产 业, 村镇成为主要投资载体, 产业布局小而全、散而 乱(叶玉瑶等, 2011)。中国在 20 世纪 90 年代进行行 政分权化和财税制度改革, 地方政府获得更多经济 发展自主权, 大量建设各类工业园区、厂房和职工宿 舍, 加速了土地非农化(叶嘉安等, 1999)。城市政 府、乡镇政府、农村集体以及个人等土地开发者“各
自为政”(闰小培等, 2006), 加剧了空间布局无序和 用地混杂(唐常春等, 2007)。随着政府出台价格调 控、土地开发等政策,珠三角产业进人调整阶段,增 速下降,建设用地扩展有所减缓(叶玉瑶等, 2011)。 同时,股份制改革推动企业的集团化、大型化,乡镇 企业逐渐由劳动力密集型向技术密集型转变(古诗 韵等, 1999), 随着集聚经济发展和区域一体化趋势, 逐渐形成密集建设带(李珽等, 2014)。

现有村镇空间研究多关注历史和农业型村镇 (王跃等, 2005; 王介勇等, 2010; 马晓冬等, 2012; 王 镜均等, 2014; 金红娜等, 2015; 杨忍等, 2015), 快速 工业化背景下村镇空间格局研究相对较少; 且相关 研究多集中在 2010 年之前(王冠贤等, 2002; 马荣华 等, 2007), 较少对当前村镇空间形态特征研究。另 一方面,已有文献多在区域尺度上对珠三角村镇空 间形态进行整体性研究, 缺乏对其内部多样性的深 人探讨和对空间型态模式的总结, 而珠三角内的东 莞、中山、佛山 3 市有着相对不同的产业发展模式, 影响土地利用的型态。因此, 本文选取东莞、中山、 佛山为研究对象(图 1), 基于土地利用数据, 从空间 分布、空间形态、功能关系 3 个方面分析珠三角村镇 建设用地空间形态特征, 比较与总结不同地区村镇 建成区空间类型,探讨其形成的主要因素, 为优化 村镇空间布局提供依据。

\section{1 数据来源与研究方法}

\section{1 数据来源}

本文数据来源包括: (1) 广东省 2015 年土地利 用现状数据, 其基于 Landsat $30 \mathrm{~m}$ 遥感影像解译得 到, 按照国家土地利用分类方法, 将土地利用类型

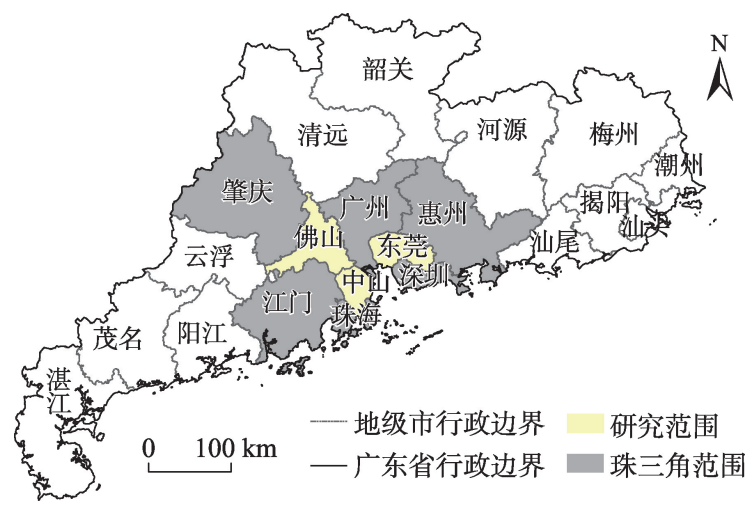

图 1 东莞、中山、佛山在广东省的地理位置

Fig.1 Location of Dongguan, Zhongshan, and Foshan cities in Guangdong Province 
划分为包括耕地、林地、草地、水域、建设用地和未 利用地在内的 6 个一级类和包括有林地、灌木林、疏 林地、其他林地和高、中、低覆盖度草地等 25 个二级 类型; (2) 东莞市 2009 年土地 “二调” 数据; (3) 中山市 域土地利用现状图(2011年); (4) 佛山市域用地现状 图(2012 年); (5)广东省市镇级行政区划边界 GIS 数 据(2015 年); (6) 广东省道路交通用地 GIS 数据(2015 年); (7) 3市的2015-2017年统计年鉴数据。

\section{2 研究方法}

在 ArcGIS 10.1 中对以上数据进行处理, 得到 东莞、中山、佛山 3 市村镇建设的土地利用类型、边
界范围、形状及空间分布信息。选取空间分布、空 间形态与功能关系 3 个方面的指标, 分析珠三角村 镇建成区空间格局与形态特征。其中,空间分布选 取斑块密度、空间离散度和空间均匀度 3 个指标分 别反映分布的密集、分散、均匀程度;空间形态选取 平均斑块面积、分形维数和景观破碎度 3 个指标来 反映用地的规模大小、形状的复杂和紧凑程度; 功 能关系选取缓冲区分析和 Moran's $I$ 指数来反映不 同功能用地之间的空间分布相关性。基于以上 8 个 指标的分析, 能充分描述村镇建成区空间的形态与 分布状况。各个指标的计算公式与涵义如表 1 所示。

\section{表 1 空间形态格局指标与方法}

Tab.1 Spatial pattern indices and methods

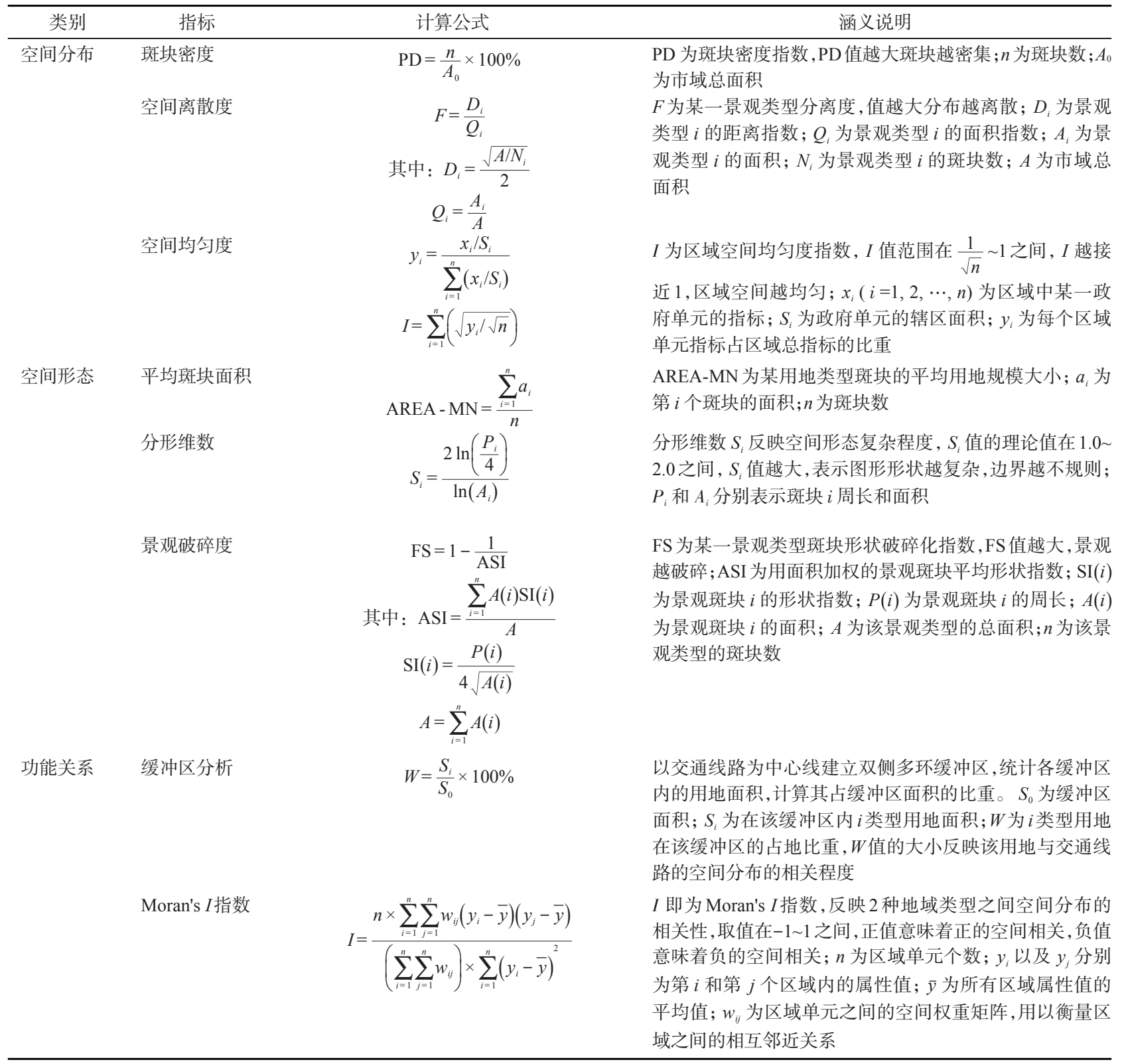


而后, 采用灰色关联分析法, 分析 3 市土地利用 空间形态格局与产业发展的相关性。灰色关联分 析法是灰色系统理论与研究方法的重要内容, 常用 于多因素相关性的量化分析, 关联度数值越高, 说 明这 2 个因素的相关性越高(赵鹏军等, 2018)。首 先, 采用均值法对空间形态格局指标和产业发展特 征指标的数值进行标准化:

$$
x_{i}^{\prime}(k)=\frac{x_{i}(k)}{x_{i}}
$$

式中: $x_{i}(k)$ 是第 $k$ 个城市第 $i$ 项指标的原始数据; $x_{i}^{\prime}(k)$ 是标准化后的数据; $x_{i}$ 为该项指标的平均 值。其次,根据以下公式计算关联系数:

$\xi_{i}(k)=\frac{\operatorname{minmin}_{i}\left|y(k)-x_{i}^{\prime}(k)\right|+\rho_{i}^{\operatorname{maxmax}_{k}}\left|y(k)-x_{i}^{\prime}(k)\right|}{\left|y(k)-x_{i}^{\prime}(k)\right|+\rho \rho_{i} \operatorname{maxmax}_{k}\left|y(k)-x_{i}^{\prime}(k)\right|}$

式中: $\xi_{i}(k)$ 为第 $k$ 个城市第 $i$ 项指标的关联系数; $y(k)$ 为第 $k$ 个城市参考指标的数据; $\rho$ 为判别系数, 用来削弱最大值过大而失真的影响, 提高关联系数 间的差异显著性, 通常取 $\rho=0.5$ 。求关联系数的平 均值, 得到关联度:

$$
r_{i}=\frac{1}{n} \sum_{k=1}^{n} \xi_{i}(k)
$$

式中: $r_{i}$ 为关联度。当 $0<r_{i} \leqslant 0.35$ 时, 两因素间相 互联系较弱; $0.35<r_{i} \leqslant 0.65$ 时, 关联为中等程度; $0.65<r_{i} \leqslant 0.85$ 时, 关联度较强; 当 $0.85<r_{i} \leqslant 1$ 时, 关 联度极强。

\section{2 形态特征与空间布局模式}

如图 2 所示, 东莞、中山、佛山的建设用地空间 整体表现出土地高度非农化、破碎化的特点。对比 而言, 东莞建设用地比重较高, 中山和佛山比重较 为接近。

\section{1 空间分布特征}

如图 3 所示, 东莞、中山、佛山建设用地空间分 布特征差异明显。这表现在以下 3 个方面: (1) 从斑 块密度来看, 东莞和中山的建设用地斑块明显比佛 山密集; (2) 从空间离散度来看, 东莞的建设用地斑 块分布最为集聚, 其次是中山, 佛山的建设用地斑 块分布最为分散; (3) 从空间均匀度看, 3 市建设用 地的分布均匀性差异不大。

首先, 从工业用地的布局特征来看, 东莞和中 山用地斑块密度较为接近, 远大于佛山。其次, 在 空间离散度方面 3 市差距悬殊, 东莞 $<$ 中山<佛山, 东莞最为集中, 佛山最为分散, 中山在二者之间。 第三, 3 市工业用地的空间分布均匀程度相当。对 于非工业的建设用地而言, 3 市的斑块密度和空间 均匀度差异较小, 而在空间离散方面存在明显差

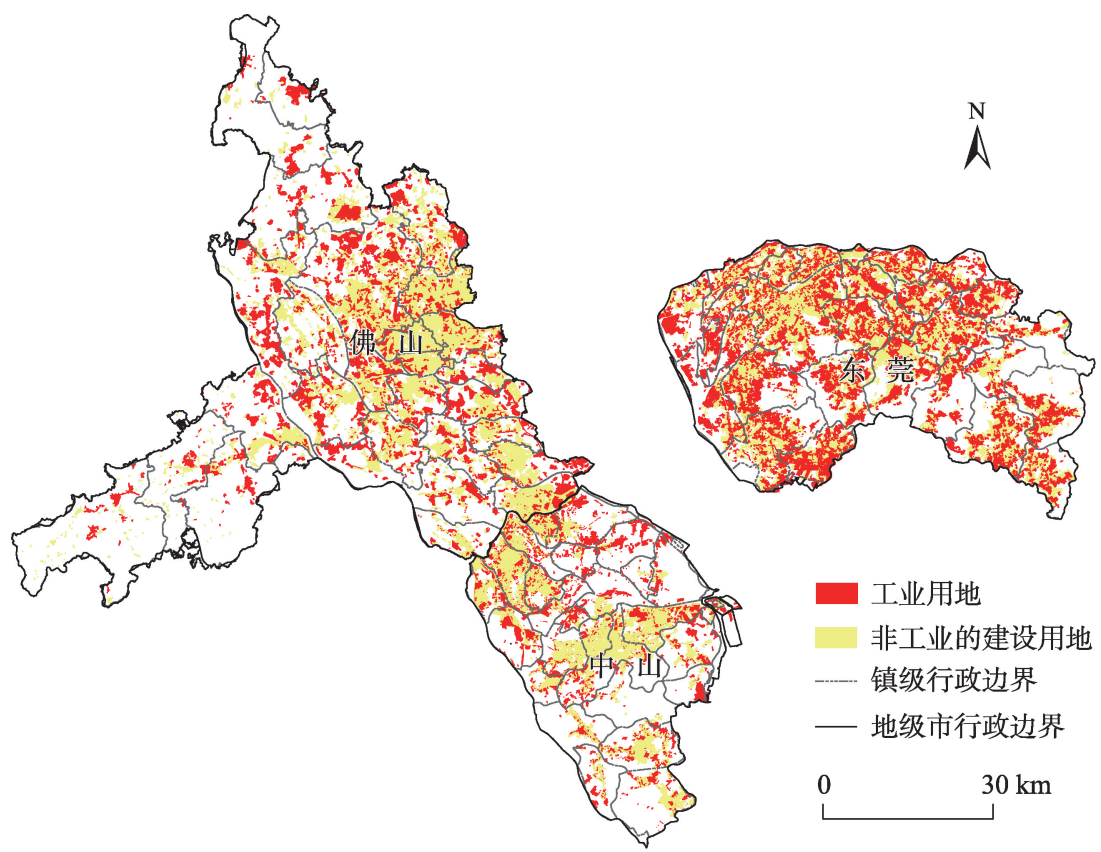

图2 2015年东莞、中山、佛山的建设用地空间分布

Fig.2 Spatial distribution of construction land in Dongguan, Zhongshan and Foshan, 2015 


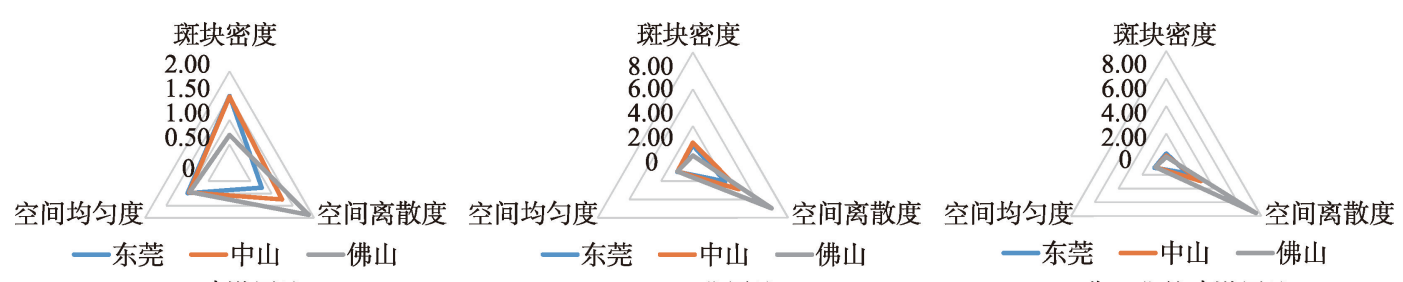

(a) 建设用地

(b) 工业用地

(c) 非工业的建设用地

图3 东莞、中山、佛山的建设用地空间分布特征比较

Fig.3 Spatial distribution characteristics of construction land in Dongguan, Zhongshan and Foshan

异, 东莞最为集中, 佛山最为分散, 中山介于二者 之间。

\section{2 空间形态特征}

如图 4所示, 3 市建设用地空间形态趋同,但也 存在较小差异。这表现在以下 3 个方面: (1) 东莞、 中山、佛山 3 市的建设用地地块普遍较小,其中中山 斑块平均规模最小, 其次是东莞, 佛山的斑块平均 规模最大; (2) 从分形维数来看, 3 市的建设用地边 界扭曲、形状不规整, 3 市差异不大; (3) 景观破碎度 结果表明, 3 市的建设用地紧凑性均不高, 土地碎化 严重: 其中东莞的建设空间格局最为破碎, 其次是 中山,佛山的空间形态最紧凑。

3 市工业用地体现出与建设用地相同的空间形 态特征。在平均斑块面积上, 佛山的工业用地规模 最大, 东莞次之, 中山最小; 在分形维数和景观破碎 度方面 3 市差异较小, 用地边界扭曲, 空间形状复 杂,土地利用较为集中。3市非工业建设用地也表现 出形状不规整、土地碎化、平均用地规模小的特征。

\section{3 功能关系特征}

2.3.1 工业用地与非工业建设用地的空间分布关系

Moran's $I$ 指数结果表明, 工业用地与非工业的 建设用地在空间分布上存在显著的正相关关系, 其 中东莞的相关性最强(0.475), 其次为中山(0.398), 佛山的相关性较弱( 0.263$)$ 。由此可见, 3 市的建设 用地混杂, 东莞的混杂特征最为显著, 中山次之, 佛 山的混杂程度最低。

\subsection{2 建设用地与交通道路的空间分布关系}

如图 5 所示, 建设用地的比重与距主要交通道 路的远近呈显著负相关关系。交通道路的廊道效 应明显,随着与道路距离的增加,道路两侧建设用 地的比重逐渐下降,这说明交通道路建设有利于周 边土地利用开发。交通道路对土地利用的影响在 3 市具有差异性,东莞建设用地对道路的依赖性最 大, 道路两侧的建设用地比重最大, 相关性最强, 远 大于中山和佛山。

\section{4 土地利用空间型态模式}

根据以上分析, 从土地利用角度将东莞、中山、 佛山的村镇建成区空间划分为 3 种类型, 分别为: 高 度破碎均匀分布型、中度碎化分散型和团状离散型 (表2)。表 2 显示,航拍图片也显示出 3 种类型之间 的差异。具体而言,东莞的土地利用表现出如下特 征: (1) 用地规模上, 建设强度大,超过了土地总量的 一半; (2) 空间形态上,平均斑块面积小,数量多,密 度大, “小而密”特点突出; 景观破碎化程度高, 形状 复杂不规整; 3 空间分布上,密集且均匀,离散程度 低; (4) 功能关系上, 建设用地沿道路集中分布, 工业 用地与非工业的建设用地相互混杂。由此可见,东 莞的村镇建设空间高度碎化、均匀分布、功能混杂。

与东莞不同,佛山的土地利用表现出“大分散、 小集中”的团状分散特点。具体而言: (1) 用地规模 上, 与东莞相比建设强度较小, 约占总土地面积的 $1 / 3$; 2) 空间形态上,平均斑块面积较大,数量少, 密

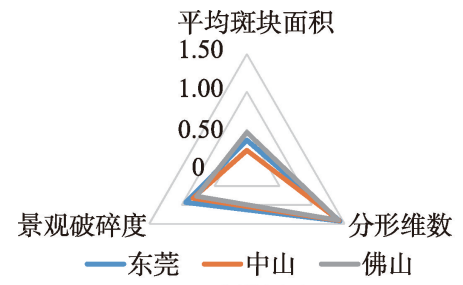

(a) 建设用地

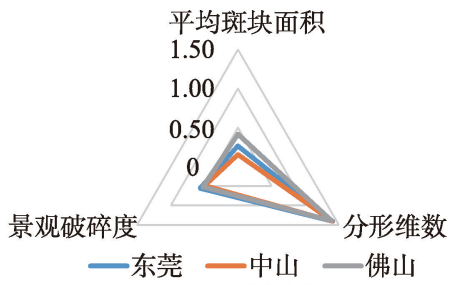

(b) 工业用地

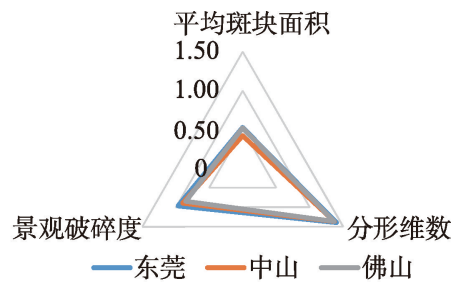

(c) 非工业的建设用地

图 4 东莞、中山、佛山的建设用地空间形态特征比较

Fig.4 Spatial pattern characteristics of construction land in Dongguan, Zhongshan and Foshan 


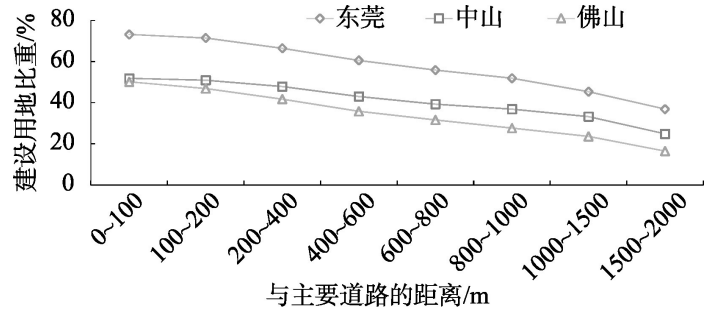

图 5 道路两侧不同缓冲区内建设用地比重

Fig.5 Percentages of construction land in different buffer zones around the roads

度小, “大而稀疏”特点突出; 景观破碎化程度低, 表 现出不规则的团块形状; (3) 空间分布不均匀,离散 程度高, 村镇建设用地存在明显疏密差异; (4) 功能 关系上,工业用地与非工业的建设用地空间具有相 关性, 但存在一定的空间距离, 功能有分区。由此 可见,佛山的村镇建设空间区域不平衡、团状分散、 功能分区。

中山的土地利用空间形态特点介于东莞与佛 山之间: (1) 用地规模上, 与佛山的建设强度相当,约 占总土地面积的 $1 / 3$; (2) 空间形态上, 平均斑块面积 小, 密度大, 呈现“小而密”的特点; 景观较为破碎, 用地形状较为不规整; (3) 空间分布较为密集、均匀,
分布较为离散; (4. 功能关系上,工业用地与非工业 的建设用地相关性较强, 地块功能分离。由此可 见, 中山的村镇建设空间中度碎化分散、功能分离。

\section{3 土地利用空间型态差异化的产业发 展原因}

如前文所述,产业发展是珠三角村镇土地利用 型态形成的主要原因, 其村镇产业结构的制度惯性 和转型应能反映土地利用形态的转变, 东莞、中山、 佛山 3 市的村镇建成区空间型态是各自发展模式在 空间上的反映。

2000 年以来, 东莞 “三来一补”企业逐渐减少, 主要被转化为私营企业和个体工商户, 个体私营经 济占比高(表 3)。由于 “三来一补”企业、私营企业和 个体工商户的用地, 大多为乡镇或农村集体土地, 用地规模较小,加上集体土地无序规划的历史原 因,导致土地高度破碎、建设用地相互混杂。

中山在 20 世纪 90 年代进行经济体制改革, 镇 级政府获得更多经济管理权,改善基础设施,建设 工业园,借助外资和民间资本, 发展民营企业,形成

表 2 珠三角地区村镇建成区空间的类型及特征

Tab.2 Types and characteristics of the spatial pattern of built-up areas in villages and towns of the Pearl River Delta

\begin{tabular}{|c|c|c|c|}
\hline 项目 & 东莞 & 中山 & 佛山 \\
\hline 类型 & 高度破碎均匀分布型 & 中度碎化分散型 & 团状离散型 \\
\hline 形态特征 & $\begin{array}{l}\text { 在各镇区均匀分布,集聚在道路两侧; 土地高 } \\
\text { 度破碎,工业用地与非工业的建设用地混杂 } \\
\text { 交错,工业用地散布在各类建设用地当中 }\end{array}$ & $\begin{array}{l}\text { 建设用地沿路分布,但路网密度相对较小; } \\
\text { 土地利用中度碎化分散,地块较为不规整, } \\
\text { 工业用地与非工业建设用地功能分离 }\end{array}$ & $\begin{array}{l}\text { 建设用地沿道路分布, 区域分布不 } \\
\text { 均匀;土地碎化程度较低,团块不规 } \\
\text { 则形状,离散分布,功能有分区 }\end{array}$ \\
\hline 分布模式 & 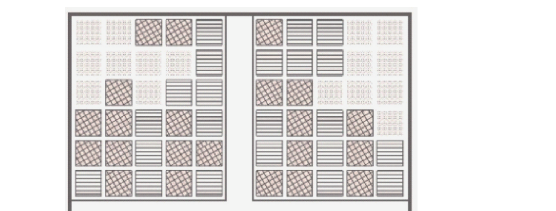 & 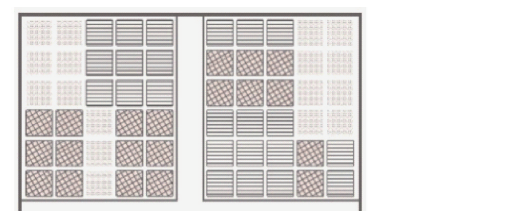 & 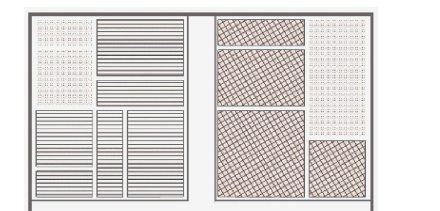 \\
\hline & 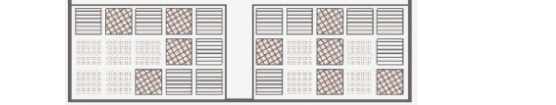 & 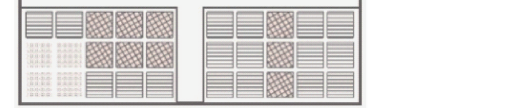 & \\
\hline \multicolumn{4}{|l|}{ 典型图谱 } \\
\hline & 道路战 & 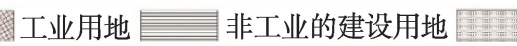 & 非建设用地 \\
\hline
\end{tabular}


表 3 按注册类型划分的东莞市企业法人单位数(2015 年)

Tab.3 Number of corporate units by registration status in Dongguan City, 2015

\begin{tabular}{ccccccccccc}
\hline 数量及比例 & 国有企业 & 集体企业 & 有限责任公司 & 外商投资 & 中外合资 & 中外合作 “三来一补”企业 & 私营企业 & 个体工商户 & 总计 \\
\hline 数量 $/$ 个 & 815 & 1471 & 11764 & 12279 & 476 & 91 & 1535 & 226499 & 456055 & 710985 \\
比例 $/ \%$ & 0.11 & 0.21 & 1.65 & 1.73 & 0.07 & 0.01 & 0.22 & 31.86 & 64.14 & 100.00 \\
\hline
\end{tabular}

注:资料来源于《东莞统计年鉴》(2016年)。

“一镇一品” 的专业镇(李珽等, 2014)。2015 年数据 显示, 中山已形成以民营企业为主的、各种经济类 型的企业(表4)。由于地方国营企业、私营企业和外 资投资加工企业的规模相对较小, 平均用地规模较 小。“一镇一品”的产业专一化特点使得中小型企业 集聚, 反映到具体的建设用地上, 工业用地与非工 业的建设用地相互分离, 但是具有空间相关性, 二 者距离较近,形成的空间形态是中度碎化分散的。

20 世纪 90 年代以来, 佛山推行农村土地股份 合作制, 集中土地引资办厂, 改变以往家庭承包经 营土地规模小的特点。企业产权制度改革, 推动大 型乡镇企业的发展, 一定程度上扭转了原村办、镇 办企业规模小、布局分散的局面(田莉, 2015)。由于 行政界限的限制, 工业建设呈现出以镇域为基础的 分散型布局。2002年行政区划调整, 顺德、南海、高 明、三水作为县级区并人佛山, 原佛山城区新设禅 城区, 各区积极引导村镇工业进人工业园区, 形成 “各自独立、多中心”的多组团发展格局。与东莞、 中山明显不同的另一点是, 佛山工业发展以重工业 为主, 上下游关联产业链较长, 而且具有规模集聚 效应,工业企业用地倾向于相互集聚。因此,佛山 的工业组团式发展, 用地呈现出大规模的团块状, 工业与非工业功能分区, 空间分布离散。

东莞、中山、佛山的村镇工业化发展各有特色, 产业特征如表 5 所示。从资金来源来看, 规模以上 工业企业中东莞的外资企业占比最高, 为 $49.07 \%$; 中山次之, 为 $31.01 \%$; 佛山仅有 $20.54 \%$ 。从产业类 型来看, 佛山以重工业为主导, 占比 $62.34 \%$; 东莞 轻、重工业并重, 重工业比例 50.18\%; 中山重工业仅 占 $38.91 \%$ 。从企业规模来看, 佛山的企业规模最
大,东莞次之,中山最小。

基于灰色关联分析, 将斑块密度、空间离散度、 空间均匀度、平均斑块面积、分形维数、景观破碎度 等 6 个空间形态格局指标与外资比例、重工业比例、 规模以上企业比例等 3 个产业发展指标的数值代人 式(1)进行标准化,而后通过式(2)计算空间形态格 局指标与产业发展指标间的关联系数,最后求平均 值, 得到关联度的计算结果(表 6$)$ 。从整体情况看, 空间形态格局与产业发展的关联程度普遍在 0.5 以 上, 说明两者具有中等或较强的相关性。具体而 言: 外资比例, 即产业发展的资金来源对斑块密度有 较强的影响; 重工业比例, 即产业类型很大程度上 影响了土地利用的空间集聚情况(空间离散度、分 形维数、景观破碎度); 规模以上企业比例, 即企业 规模对空间分布的均匀和斑块的大小影响最大。 由此可见,产业发展在资金来源、产业类型、企业规 模 3 个方面对村镇建成区空间型态有较大的影响。

\section{4 结论与讨论}

20 世纪 80 年代以来, 珠三角村镇自下而上发 展起各具特色的工业企业, 土地利用迅速向非农化 转变。本文通过 GIS 空间分析、分形维数、景观破 碎度等空间形态指标测度以及灰色关联度分析, 从 土地利用角度深人分析了珠三角东莞、中山、佛山 的村镇建成区空间形态特征, 总结了村镇工业化背 景下所形成的土地利用空间模式。

整体来看, 珠三角村镇形成了密集的建设空 间,形态复杂, 土地碎化严重。在空间分布上, 建设 空间在宏观尺度上均匀分布, 在微观尺度上集聚。

表 4 按注册类型划分的中山市企业法人单位数(2015 年)

Tab.4 Number of corporate units by registration status in Zhongshan City, 2015

\begin{tabular}{cccccccccccc}
\hline $\begin{array}{c}\text { 数量 } \\
\text { 及比例 }\end{array}$ & $\begin{array}{c}\text { 国有 } \\
\text { 企业 }\end{array}$ & $\begin{array}{c}\text { 集体 } \\
\text { 企业 }\end{array}$ & $\begin{array}{c}\text { 股份 } \\
\text { 合作 }\end{array}$ & $\begin{array}{c}\text { 联营 } \\
\text { 企业 }\end{array}$ & $\begin{array}{c}\text { 有限责任 } \\
\text { 公司 }\end{array}$ & $\begin{array}{c}\text { 股份有限 } \\
\text { 公司 }\end{array}$ & $\begin{array}{c}\text { 私营 } \\
\text { 企业 }\end{array}$ & $\begin{array}{c}\text { 其他 } \\
\text { 内资 }\end{array}$ & $\begin{array}{c}\text { 港澳台 } \\
\text { 投资 }\end{array}$ & $\begin{array}{c}\text { 外商 } \\
\text { 投资 }\end{array}$ & $\begin{array}{c}\text { 总计 } \\
\text { 数量 } / \text { 个 }\end{array}$ \\
1620 & 2585 & 159 & 197 & 23419 & 806 & 49731 & 4261 & 2173 & 1107 & 86058 \\
比例 $/ \%$ & 1.88 & 3.00 & 0.18 & 0.23 & 27.21 & 0.94 & 57.79 & 4.95 & 2.53 & 1.29 & 100.00 \\
\hline
\end{tabular}

注:资料来源于《中山统计年鉴》(2016年)。 
表 5 东莞、中山、佛山的规模以上工业企业类型比较(2016年)

Tab.5 Types of industrial enterprises above designated size in Dongguan, Zhongshan and Foshan, 2016

\begin{tabular}{|c|c|c|c|c|c|}
\hline \multicolumn{3}{|c|}{ 企业类型 } & 东莞 & 中山 & 佛山 \\
\hline \multicolumn{3}{|c|}{ 全市规模以上工业企业数量/个 } & 5869 & 3089 & 6627 \\
\hline \multicolumn{3}{|c|}{ 全市规模以上工业企业比例/\% } & 4.82 & 3.29 & $5.93^{\circ}$ \\
\hline \multicolumn{3}{|c|}{ 外资企业比例/\% } & 49.07 & 31.01 & 20.54 \\
\hline \multirow[t]{4}{*}{ 按轻、重工业划分 } & 轻工业 & 数量 $/$ 个 & 2924 & 1887 & 2496 \\
\hline & & 比例/\% & 49.82 & 61.09 & 37.66 \\
\hline & 重工业 & 数量 $/$ 个 & 2945 & 1202 & 4131 \\
\hline & & 比例/\% & 50.18 & 38.91 & 62.34 \\
\hline \multirow[t]{8}{*}{ 按规模划分 } & 大型 & 数量/个 & 266 & 107 & 375 \\
\hline & & 比例/\% & 4.53 & 3.46 & 5.66 \\
\hline & 中型 & 数量 $/$ 个 & 1638 & 573 & 1591 \\
\hline & & 比例/\% & 27.91 & 18.55 & 24.01 \\
\hline & 小型 & 数量/个 & 3760 & 2336 & 4366 \\
\hline & & 比例/\% & 64.07 & 75.62 & 65.88 \\
\hline & 微型 & 数量 $/$ 个 & 205 & 73 & 295 \\
\hline & & 比例 $/ \%$ & 3.49 & 2.36 & 4.45 \\
\hline
\end{tabular}

注: *由于缺乏高明区和三水区统计数据,此数值为佛山市南海区、禅城区、顺德区的统计数据测算得到; 资料来源于《东莞统计年鉴》 (2017年)、《中山统计年鉴》(2017年)、《佛山统计年鉴》(2017年)、《禅城区统计年鉴》(2017年)、《南海区统计年鉴》(2017年)、《顺德区统计年鉴》 (2017年)。

表 6 空间形态格局与产业发展关联度

Tab.6 Coupling degree between spatial pattern and industrial development

\begin{tabular}{|c|c|c|c|c|}
\hline 指标 & 外资比例 & 重工业比例 & 规模以上企业比例 & 关联度比较 \\
\hline 斑块密度 & 0.669 & 0.543 & 0.544 & 外资比例 $>$ 规模以上企业比例>重工业比例 \\
\hline 空间离散度 & 0.546 & 0.678 & 0.652 & 重工业比例 $>$ 规模以上企业比例 $>$ 外资比例 \\
\hline 空间均匀度 & 0.517 & 0.575 & 0.578 & 规模以上企业比例>重工业比例>外资比例 \\
\hline 平均斑块面积 & 0.470 & 0.752 & 0.766 & 规模以上企业比例 $>$ 重工业比例>外资比例 \\
\hline 分形维数 & 0.496 & 0.654 & 0.607 & 重工业比例 $>$ 规模以上企业比例 $>$ 外资比例 \\
\hline 景观破碎度 & 0.546 & 0.594 & 0.592 & 重工业比例 $>$ 规模以上企业比例 $>$ 外资比例 \\
\hline
\end{tabular}

在功能关系上, 建设用地依赖于交通道路, 沿道路 扩展延伸,工业用地与非工业用地混杂交错。

不同工业化模式主导的村镇建设空间有一定 差异, 形成了 3 种村镇建成区空间类型, 分别是东莞 的高度破碎均匀分布型、中山的中度碎化分散型、 佛山的团状离散型。东莞建设密度最大, 中山次 之, 佛山最低。就建设用地整体而言, 东莞建设用 地高度混杂, 破碎的特征最为显著, 其斑块数量最 多, 斑块密度最高, 平均斑块面积最小, 分形维数和 景观破碎度最大。与东莞不同, 佛山的建设用地景 观破碎度最小, 斑块较为稀疏, 而且平均斑块面积 更大, 呈现出 “大而稀疏”的特点, 村镇工业用地集 中人园, 功能分区明显。中山的建设用地特点介于 东莞与佛山之间, 斑块数量多, 平均斑块面积较小, 土地碎化与混杂程度低于东莞而高于佛山。
东莞、中山、佛山的村镇建成区空间型态差异 主要是由各自产业发展差异造成的。20世纪 80 年 代以来,东莞在村镇集体用地上形成“三来一补”的 外向型企业, 而后转化为私营个体企业, 工业企业 用地规模小, 易形成高度碎化、相互混杂的空间形 态。中山以国营经济为龙头发展起以民营企业为 主体的“一镇一品”经济, 各镇产业专一化, 以轻工 业为主, 工业企业用地规模较小。佛山产业以重工 业为主, 企业规模较大, 上下游产业关联而导致用 地集聚,工业用地呈组团状集聚分布。未来研究可 以结合政策与人口等因素展开全面分析。

当前, 珠三角空间结构正处在新一轮的转型 中, 粤港澳大湾区的规划建设是转型的主要推动 力, 将极大影响珠三角村镇空间转型并提出挑战。 粤港澳大湾区规划建设的实质是要促进大湾区城 
市群发展, 发挥港澳独特优势, 提升在国家经济发 展和对外开放中的地位与功能。粤港澳大湾区建 设要求并增进珠三角空间结构的紧凑与高效。而 村镇空间混乱无序发展不利于土地高效集约利用， 高密度、混杂、碎化的建设空间造成土地利用不经 济, 浪费严重, 人居环境差, 治理难度大和成本高, 会对湾区建设形成阻力。各级政府在加强城乡规 划与公共管理的同时, 应结合工业转型升级的趋 势, 合理布局产业空间,将居住、商业和产业用地按 比例和尺度合理配置, 确保污染性的产业用地与生 态农地等用地有效分离, 优化村镇空间结构, 确保 土地的高效利用。现阶段的湾区建设主要集中在 交通基础设施建设和互联互通上,珠三角村镇空间 转型应在整合破碎土地斑块的同时, 各级政府也应 调整土地利用模式, 以适应未来交通基础设施的发 展, 例如采用 TOD(transit-oriented development)模 式调整村镇土地利用, 同时促进村镇空间转型和大 湾区发展。

\section{参考文献(References)}

丁俊, 王开泳. 2016. 珠江三角洲城市群工业生产空间格局、 形态特征及影响因素 [J]. 地理科学进展, 35(5): 610-621. [Ding J, Wang K Y. 2016. Spatial pattern and morphological characteristics of industrial production space and influential factors in the Pearl River Delta urban agglomeration. Progress in Geography, 35(5): 610-621. ]

古诗韵, 阎小培. 1999. 珠三角乡镇企业发展的时空变化特 征 [J]. 中山大学学报(自然科学版), 38(5): 92-97. [Gu S Y, Yan X P. 1999. Temporal and spatial disparities of the township enterprises in the Pearl River Delta of China since the late 1970s. Acta Scientiarum Naturalium Universitatis Sunyatse, 38(5): 92-97. ]

顾朝林, 吴莉娅. 2008. 中国城市化研究主要成果综述 [J]. 城 市问题, (12): 2-12. [Gu C L, Wu L Y. 2008. Summary of the main results of the research of China's urbanization. Urban Problems, (12): 2-12. ]

韩非, 蔡建明. 2011. 我国半城市化地区乡村聚落的形态演 变与重建 [J]. 地理研究, 30(7): 1271-1284. [Han F, Cai J M. 2011. The evolution and reconstruction of peri- urban rural habitat in China. Geographical Research, 30(7): 12711284. ]

金红娜, 车震宇. 2015. 大理旅游村镇空间形态变化比较研 究: 以大理沙溪镇、新华村为例 [J]. 华中建筑, (7): 83-87. [Jin H N, Che Z Y. 2015. Comparative study on space morphological changes of Dali tourist towns and villages: Taking Shaxi Town and Xinhua Village for example. Hua- zhong Architecture, (7): 83-87. ]

李立勋. 1997. 珠江三角洲乡镇企业发展的地域特征 [J]. 热 带地理, 17(1): 47-52. [Li L X. 1997. The development features of the township enterprises in the Pearl River Delta. Tropical Geography, 17(1): 47-52.]

李珽, 符文颖. 2014. 珠江三角洲城市空间形态及其演化机 制对比 [J]. 地理科学进展, 33(5): 678-688. [Li T, Fu W Y. 2014. Inter- city comparative study of urban morphology and mechanisms in the Pearl River Delta. Progress in Geography, 33(5): 678-688. ]

梁励韵, 刘晖. 2014. 工业化视角下的小城镇形态演变: 以顺 德北浫镇为例 [J]. 城市问题, (4): 48-52. [Liang L Y, Liu H. 2014. The spatial form evolution of small towns under the perspective of industrialization: A case study of Beijiao Town in Shunde City. Urban Problems, (4): 48-52. ]

林媚珍, 许阳萍, 方碧真, 等. 2010. 中山市土地景观格局动 态变化分析 [J]. 广州大学学报(自然科学版), 9(3): 8995. [Lin M Z, Xu Y P, Fang B Z, et al. 2010. Analysis of dynamic land landscape pattern in Zhongshan. Journal of Guangzhou University (Natural Science Edition), 9(3): 8995. ]

马荣华, 顾朝林, 蒲英霞, 等. 2007. 苏南沿江城镇扩展的空 间模式及其测度 [J]. 地理学报, 62(10): 1011-1022. [Ma R H, Gu C L, Pu Y X, et al. 2007. Urban spatial sprawl pattern and metrics in south of Jiangsu Province along the Yangtze River. Acta Geographica Sinica, 62(10): 1011-1022. ]

马晓冬, 李全林, 沈一. 2012. 江苏省乡村聚落的形态分异及 地域类型 [J]. 地理学报, 67(4): 516-525. [Ma X D, Li Q L, Shen Y. 2012. Morphological difference and regional types of rural settlements in Jiangsu Province. Acta Geographica Sinica, 67(4): 516-525. ]

唐常春, 陈烈, 王爱民, 等. 2007. 快速工业化区域土地利用 变迁机制研究: 发展模式视角: 以佛山市南海区为例 [J]. 热带地理, 27(1): 49-53. [Tang C C, Chen L, Wang A M, et al. 2007. A study on land utilization change in rapid industrialization regions from the view of dexelopment patterm: A case study of Nanhai District, Foshan. Tropical Geography, 27(1): 49-53. ]

田莉. 2015. 我国半城市化地区土地利用的区域比较: 时空 模式与形成机制 [M]. 北京: 中国建筑工业出版社. [Tian L. 2015. Regional comparison of land use in peri-urban areas of China: Spatio-temporal pattern and driving forces. Beijing, China: China Architecture\& Building Press. ]

王爱民, 缪勃中, 陈树荣. 2007. 广州市工业用地空间分异及 其影响因素分析 [J]. 热带地理, 27(2): 132-138. [Wang A M, Mou B Z, Chen S R. 2007. Spatial differentiation and impact factors of industrial land-use in Guangzhou. Tropical Geography, 27(2): 132-138. ] 
王冠贤, 陈冰. 2002. 珠三角经济区村落形态的演变分析: 以 中山冈东村为例 [J]. 规划师, 18(8): 75-78. [Wang G X, Chen B. 2002. Analysis on the evolution of village form in the Pearl River Delta: A cases tudy of Guangdong Village. Planers, 18(8): 75-78. ]

王介勇, 刘彦随, 陈玉福. 2010. 黄淮海平原农区典型村庄用 地扩展及其动力机制 [J]. 地理研究, 29(10): 1833-1840. [Wang J Y, Liu Y S, Chen Y F. 2010. Spatial expansion pattern and its dynamic mechanism of typical rural settlements inin Huang-Huai-Hai Plain. Geographical Research, 29(10): 1833-1840. ]

王镜均, 王勇, 李广斌. 2014. 苏南村落空间分异的三种典型 模式及比较: 以蒋巷坞坻树山三村为例 $[\mathrm{J}]$. 现代城市研 究, 29(12): 75-81. [Wang J J, Wang Y, Li G B. 2014. Three typical models and comparison of the village space differentiation in southern Jiangsu: A case study of Jiangxiang, Wuqiu and Shushan. Modern Urban Research, 29(12): 7581. ]

王开泳, 陈田. 2008. 珠江三角洲都市经济区地域构成的判 别与分析 [J]. 地理学报, 63(8): 820-828. [Wang K Y, Chen T. 2008. The classification and analysis of areal topology in extended metropolitan area of Pearl River Delta. Acta Geographica Sinica, 63(8): 820-828. ]

王跃, 陈亚莉. 2005. 苏州城郊村镇分布特征 [J]. 地理学报, 60(2): 229-236. [Wang Y, Chen Y L. 2005. Distribution characteristics of villages and towns in suburbs of Suzhou. Acta Geographica Sinica, 60(2): 229-236. ]

伍灵晶, 全德, 李贵才. 2017. 地方政府驱动下的城市建成空 间特征差异: 以广州、东莞为例 [J]. 地理研究, 36(6): 1029-1041. [Wu L J, Tong D, Li G C. 2017. Differences of the urban spatial structure driven by local governments: Cases study in Guangzhou and Dongguan. Geographical Research, 36(6): 1029-1041. ]

许学强, 张蓉. 1995. 珠江三角洲的工业化与城市化 [J]. 地理 学与国土研究, 11(1): 1-8. [Xu X Q, Zhang R. 1995. Industrialization and urbanization in the Pearl River Delta. Geography and Territorial Research, 11(1): 1-8. ]

薛凤旋, 杨春. 1997. 外资: 发展中国家城市化的新动力: 珠 江三角洲个案研究 [J]. 地理学报, 52(3): 3-16. [Xue F X, Yang C. 1997. Foreign capital: The new dynamic force of urbanization in the developing countries: Study on the example of the Pearl River Delta. Acta Geographica Sinica, 52(3): 3-16. ]

间小培, 毛蒋兴, 普军. 2006. 巨型城市区域土地利用变化的 人文因素分析: 以珠江三角洲地区为例 [J]. 地理学报, 61 (6): 613-623. [Yan X P, Mao J X, Pu J. 2006. Research on the human dimensions of land use changes in the megaurban region: A case study of the Pearl River Delta. Acta
Geographica Sinica, 61(6): 613-623. ]

杨宝龙, 方元, 冯徽徽, 等. 2009. 东莞市城镇用地扩张的时 空特征分析 [J]. 地球信息科学学报, 11(5): 5684-5690. [Yang B L, Fang Y, Feng H H, et al. 2009. Construction land expansion in urbanization process in Dongguan. Journal of Geo-Information Science, 11(5): 5684-5690. ]

杨忍, 刘彦随, 龙花楼, 等. 2015. 基于格网的农村居民点用 地时空特征及空间指向性的地理要素识别: 以环渤海地 区为例 [J]. 地理研究, 34(6): 1077-1087. [Yang R, Liu Y S, Long H L, et al. 2015. Spatial-temporal characteristics of rural residential land use change and spatial directivity identification based on grid in the Bohai Rim in China. Geographical Research, 34(6): 1077-1087. ]

叶嘉安, 黎夏. 1999. 珠江三角洲经济发展、城市扩张与农田 流失研究: 以东莞市为例 [J]. 经济地理, 19(1): 68-73. [Ye J A, Li X. 1999. Economic development, urban sprawl, and agricultural land loss in the Pearl River Delta. China. Economic Geography, 19(1): 68-73. ]

叶玉瑶, 张虹鸥. 2007. 珠江三角洲城市群空间集聚与扩散 [J]. 经济地理, 27(5): 773-776. [Ye Y Y, Zhang H O. 2007. The Spatial agglomeration and dispersion in the Pearl River Delta. Economic Geography, 27(5): 773-776. ]

叶玉瑶, 张虹鸥, 刘凯, 等. 2010. 地理区位因子对建设用地 扩展的影响分析: 以珠江三角洲为例 [J]. 地理科学进展, 29(11): 1433-1441. [Ye Y Y, Zhang H O, Liu K, et al. 2010. Impact of site factors on expansion of construction land: A case study in the Pearl River Delta. Progress in Geography, 29(11): 1433-1441. ]

叶玉瑶, 张虹鸥, 许学强, 等. 2011. 珠江三角洲建设用地扩 展与经济增长模式的关系 [J]. 地理研究, 30(12): 22592271. [Ye Y Y, Zhang H O, Xu X Q, et al. 2011. Study on the relationship between construction land expansion and economic growth pattern in the Pearl River Delta. Geographical Research, 30(12): 2259-2271. ]

赵鹏军, 刘迪. 2018. 中国小城镇基础设施与社会经济发展 的关联分析 [J]. 地理科学进展, 37(9): 1245-1256. [Zhao P J, Liu D. 2018. Analysis of the relationships between infrastructure and socioeconomic development in towns of China. Progress in Geography, 37(9): 1245-1256. ]

郑艳婷, 刘盛和, 陈田. 2003. 试论半城市化现象及其特征: 以广东省东莞市为例 [J]. 地理研究, 22(6): 760-768. [Zheng Y T, Liu S H, Chen T. 2003. The characteristics of peri-urbanization region: A case study of Dongguan Municipality in Guangdong Province. Geographical Research, 22 (6): 760-768. ]

Chen M N, Wang D D. Yu K P, et al. 2013. Urbanization effect of highways in the Pearl River Delta [J]. Journal of Landscape Research, 5(11): 8-12, 15. 
Chen Y, Wen Y, Li Z G. 2017. From blueprint to action: The transformation of the planning paradigm for desakota in China [J]. Cities, 60: 454-465.

Dai J, Wang K, Gao X. 2010. Spatial structure and land use control in extended metropolitan region of Zhujiang River Delta, China [J]. Chinese Geographical Science, 20(4): 298-308.

Fan F, Wang Y, Qiu M, et al. 2009. Evaluating the temporal and spatial urban expansion patterns of Guangzhou from 1979 to 2003 by remote sensing and GIS methods [J]. International Journal of Geographical Information Science,
23(11): 1371-1388.

Sui D Z, Hui Z. 2001. Modeling the dynamics of landscape structure in Asia's emerging desakota regions: A case study in Shenzhen [J]. Landscape and Urban Planning, 53(1): 37-52.

van Wee B. 2002. Land use and transport: research and policy challenges [J]. Journal of Transport Geography, 10(4): 259-271.

Weng Q. 2002. Land use change analysis in the Zhujiang Delta of China using satellite remote sensing, GIS and stochastic modelling [J]. Journal of Environmental Management, 64(3): 273-284.

\title{
Spatial patterns of village and town built areas in the Pearl River Delta: A land-use perspective
}

\author{
LI Jiheng ${ }^{1,2}$, GONG Yue ${ }^{1,2^{*}}$, LI Guicai ${ }^{1,2}$ \\ (1. School of Urban Planning and Design, Peking University Shenzhen Graduate School, Shenzhen 518055, Guangdong, China; \\ 2. Laboratory for Urban Future, Peking University (Shenzhen), Shenzhen 518055, Guangdong, China)
}

\begin{abstract}
During China's rural industrialization, land in villages and towns has been rapidly transformed into non- agricultural use. The Pearl River Delta in South China is the most representative of China's rural industrialization and urbanization. In the Pearl River Delta, the cities of Dongguan, Zhongshan, and Foshan are typical cases of both rural industrialization and land-use change. The dataset used in this study includes the landuse data of 2015 in Guangdong Province and the land-use data of the three cities between 2009 and 2015. This dataset provides valuable information on the post-2010 spatial structure of villages and towns in the Pearl River Delta. Based on this dataset, we examined the current (around the mid-2010s) spatial conditions of villages and towns in the Pearl River Delta. We first analyzed the spatial attributes of construction land. The analysis was based on eight indices or methods: land patch density index, spatial discrete index, spatial uniformity index, the mean of land patch area, fractal dimension index, landscape fragmentation index, buffer analysis, and Moran's $I$ analysis. Then, we analyzed the spatial distribution relations between industrial and non-industrial land uses, and between construction land and transportation land through a statistical analysis. Finally, we discussed the industrial factors of the detected spatial pattern through the gray associative analysis. Our findings indicate a high fragmentation and even distribution pattern of village and town built-up areas in Dongguan, agglomerated and discrete pattern in Foshan, and medium level fragmentation and discreteness in Zhongshan. Diverse industrial development in the three cities had a major impact on the formation of the spatial patterns. In the future, the transformation of the spatial pattern of built-up areas in villages and towns in the Pearl River Delta must coordinate with the industrial development and the ongoing development of the Guangdong-Hong KongMacau Great Bay Area. Approaches to facilitating the transformation include the modification of the industrial structure and an adjustment of land use and transportation across these villages and towns. This article aimed to reveal the current spatial patterns of crucial rural-to-urban transformation in a rapidly urbanizing region and to provide relevant policy recommendations. The results may contribute to our understanding of China's continuous rural urbanization and industrialization.
\end{abstract}

Keywords: built-up area; spatial pattern; land use; industrial factor; villages and towns in the Pearl River Delta 